\title{
Expression status of folate receptor alpha is a predictor of survival in pancreatic ductal adenocarcinoma
}

\author{
Lei Cai $^{1,2, *}$, Theodoros Michelakos ${ }^{1, *}{ }^{,}$Cristina R. Ferrone ${ }^{1}$, Liyuan Zhang ${ }^{1}$, Vikram \\ Deshpande $^{3}$, Qi Shen ${ }^{3}$, Albert DeLeo4, Teppei Yamada ${ }^{1}$, Gong Zhang ${ }^{1}$, Soldano \\ Ferrone $^{1,5}$ and Xinhui Wang ${ }^{1}$ \\ ${ }^{1}$ Division of Surgical Oncology, Department of Surgery, Massachusetts General Hospital, Harvard Medical School, Boston, \\ MA, USA \\ ${ }^{2}$ Department of Hepatobiliary, Southwest Hospital, Third Military Medical University, Chongqing, China \\ ${ }^{3}$ Department of Pathology, Massachusetts General Hospital, Harvard Medical School, Boston, MA, USA \\ ${ }^{4}$ University of Pittsburgh Cancer Institute, University of Pittsburgh, Pittsburgh, PA, USA \\ ${ }^{5}$ Department of Orthopaedic Surgery, Massachusetts General Hospital, Harvard Medical School, Boston, MA, USA \\ * Lei Cai and Theodoros Michelakos contributed equally to this paper \\ Correspondence to: Xinhui Wang, email: XWANG30@mgh.harvard.edu \\ Keywords: folate receptor alpha, pancreatic ductal adenocarcinoma, predictor of survival, smoking, alcohol consumption \\ Received: January 28, $2017 \quad$ Accepted: March 01, $2017 \quad$ Published: April 05, 2017 \\ Copyright: Cai et al. This is an open-access article distributed under the terms of the Creative Commons Attribution License \\ (CC-BY), which permits unrestricted use, distribution, and reproduction in any medium, provided the original author and source \\ are credited.
}

\section{ABSTRACT}

Pancreatic ductal adenocarcinoma (PDAC) has one of the poorest prognosis among malignancies. Thus, the identification of markers useful in developing innovative diagnostic and therapeutic methods is an imperative need. Folate receptor alpha (FR $\alpha$ ) has been associated with prognosis in several cancers and has served as a target of novel anti-tumor therapies. However, FR $\alpha$ expression in PDAC and its correlation with the clinical course of the disease has not been thoroughly investigated. In this study, we analyzed FRo expression in 140 PDAC specimens and 7 PDAC cell lines in order to define the significance of FR $\alpha$ expression in PDAC and its potential role as a target for immunotherapy. Immunohistochemical analysis demonstrated that FR $\alpha$ expression intensity was low, intermediate and high in 22(16\%), 73(52\%) and 45(32\%) PDACs, respectively. The staining was located in both membrane and cytoplasm in most cases $(123,88 \%)$. Lower $F R \alpha$ expression was associated with cigarette smoking $(p<0.001)$, alcohol consumption $(p<0.001)$, and lymphovascular invasion $(p=0.002)$. Additionally, lower FRa expression was associated with poor overall survival (5-year overall survival: low $13 \%$, intermediate $31 \%$, high $33 \%$; $p=0.006$ ). FR $\alpha$ expression $(H R=0.61 ; p=0.03)$ and Charlson Comorbidity Index $(H R=1.16 ; p=0.01)$ emerged as independent predictors of survival. The analysis by flow cytometry of 7 PDAC cell lines (AsPC-1, Capan-2, MIA PaCa-2, PANC-1, PDAC2, PDAC3, and PDAC5) demonstrated the highest expression of FRa on the PDAC3 cell line (45\%). Therefore, a higher FRa expression is predictive of a favorable prognosis in PDAC and $\mathrm{FR} \alpha$ may represent a promising target for novel treatments, including immunotherapy.

\section{INTRODUCTION}

Pancreatic Ductal Adenocarcinoma (PDAC) continues to have one of the worst outcomes of any malignancy. It is the fourth most common cause of cancer death in the United States [1,2]. Resection is currently the only curative method, however, the 5-year overall survival rate after surgical resection is less than 5\% [3]. Unfortunately, however, most patients present with advanced unresectable and/or metastatic 
tumors. Although major risk factors for PDAC, namely, smoking [4, 5], excessive alcohol consumption [6], meat-rich diet and diabetes [7], have been identified, diagnostic methods using specific markers to predict the occurrence of PDAC are lacking. However, the survival benefit of perioperative therapeutic modalities, such as chemotherapy and chemo-radiation therapy, has been demonstrated in large-scale randomized controlled trials. Consequently, efforts are being made to identify relevant factors and/or markers that predict a high risk of recurrence and poor prognosis, which may help to optimize perioperative therapeutic approaches for those patients with resectable PDAC [8,9]. Clearly, it is urgent to understand the pathogenesis of PDAC to aid in the identification of markers useful in developing innovative diagnostic and therapeutic methods for this disease.

A potential marker for PDAC is Folate Receptor Alpha (FR $\alpha$, also known as folate binding protein [FBP]), a glycosylphosphatidylinositol-linked protein with high affinity for folate (folic acid, or vitamin B9), which acts by an endocytosis mechanism. It belongs to one of the two classes of folate transport, the other class represented by the reduced folate carrier [10].

Three FR protein isoforms have been discovered - referred to as FR $\alpha, \operatorname{FR} \beta$ and FR $\gamma$ - each with tissuespecific distribution and folate binding potential. At the gene level, these three FR isoforms have similar highly conserved sequences (about 70\% identity) in the open reading frame encoded by exons 4 through 7 in the 3 ' region of the gene but differ in the 5' untranslated region encoded by exons 1 through 4 [11-12]. These three isoforms can differ in tissue expression, function, and biochemical properties [12]. FR $\alpha$ is the most widely studied FR protein isoform and mediates the transfer of one-carbon units by folate, which is necessary for proper synthesis of purines, pyrimidines and therefore the synthesis of DNA and RNA. Furthermore, folate is also involved in the methylation of DNA, proteins and phospholipids [13]. Related to its crucial metabolic roles, FR $\alpha$ overexpression or deficiency, through folate uptake, can result in a faster or slower cell growth rate and lead to abnormally methylated genes and faulty DNA replication $[13,14]$.

$\mathrm{FR} \alpha$ is expressed at elevated levels in normal pneumocytes, thymocytes and renal tubules. However, it is dysregulated in a wide variety of human malignancies [15], such as pituitary [16], lung [17-20], breast [21], colorectal $[22,23]$, and ovarian cancers [24-26]. Furthermore, FR $\alpha$ expression levels have been associated with prognosis in these types of cancers. To date, however, the association of FR $\alpha$ expression with clinicopathological characteristics and prognosis in PDAC has not been clearly defined. In this study, we analyzed FR $\alpha$ expression levels in resected PDAC specimens and PDAC cell lines in order to define the potential significance of $\mathrm{FR} \alpha$ expression in PDAC tumors relative to the clinicopathological characteristics and prognosis of this disease.

\section{RESULTS}

\section{Clinicopathologic features of the overall patient cohort}

Samples from 156 patients who underwent pancreatic resection at our institution were analyzed. However, of those, samples from 16 patients were excluded from further analysis: 9 for insufficient number of cores, and 7 for inadequate follow-up. The clinical characteristics of the patients are summarized in Table 1. The median age at the time of pancreatectomy was 70.0 years (interquartile range: 60-76), and 77 (55.0\%) patients were female. The majority of patients had stage IIB disease $(69.3 \%)$ and $85(60.7 \%)$ had moderately differentiated tumors. Post-operatively, 65 patients $(46.4 \%)$ received adjuvant chemo-radiotherapy, $20 \quad(14.3 \%)$ received chemotherapy alone and one $(0.7 \%)$ radiotherapy alone.

\section{FRa expression in PDAC specimens}

The level of expression of FR $\alpha$ in tumor specimens obtained from the 140 PDAC patients was determined by IHC analysis as previously detailed. FR $\alpha$ expression intensity was found to be low in $22(16 \%)$, intermediate in $73(52 \%)$ and high in $45(32 \%)$ specimens from the 140 PDAC patients (Figure 1A-C). The vast majority of samples $(123,88 \%)$ showed both membranous and cytoplasmic staining, whereas in the remaining cases $(17,12 \%)$ only cytoplasmic staining was detected. Compared with paraneoplasic tissues, membranous and/ or cytoplasmic expression intensity of $\mathrm{FR} \alpha$ was markedly lower in PDAC (Figure 1B-1C vs 1D). The inter-rater reliability for the FR $\alpha$ expression intensity assessment was almost perfect (Cohen's $\kappa=0.81, \mathrm{p}<0.001$ ).

\section{The relationship between the intensity of FR $\alpha$ expression in PDAC patient specimens and the patients' clinicopathology characteristics}

Smoking and alcohol consumption were significantly associated with lower $\operatorname{FR} \alpha$ expression intensity. The percentages of smokers in each FR $\alpha$ expression group were as follows: low FR $\alpha$ expression intensity: 20 out of $22(90.9 \%)$, intermediate: 45 out of $73(61.6 \%)$, high: 10 out of $45(22.2 \%)(p<0.001)$. The percentages of alcohol users in each FR $\alpha$ expression group were as follows: low FR $\alpha$ expression intensity: 16 out of $22(72.7 \%)$, intermediate: 23 out of 73 (31.5\%), high: 12 out of $45(26.7 \%)(\mathrm{p}<0.001)$ (Table 1). Additionally, lymphovascular invasion was significantly associated with lower FR $\alpha$ expression intensity (low: $81.8 \%$, intermediate: 58.9\%, high: $37.8 \%, \mathrm{p}=0.002$ ) (Table 1). There was no 
Table 1: Correlation of PDAC FR $\alpha$ expression intensity and clinicopathological characteristics in 140 PDAC patients

\begin{tabular}{|c|c|c|c|c|c|c|c|c|c|}
\hline & \multicolumn{8}{|c|}{ FR $\alpha$ expression intensity } & \multirow{3}{*}{ p-value } \\
\hline & \multicolumn{2}{|c|}{$\begin{array}{c}\text { Low } \\
\mathrm{N}=22(16 \%)\end{array}$} & \multicolumn{2}{|c|}{$\begin{array}{l}\text { Intermediate } \\
\mathrm{N}=73(52 \%)\end{array}$} & \multicolumn{2}{|c|}{$\begin{array}{c}\text { High } \\
\mathrm{N}=45(32 \%)\end{array}$} & \multicolumn{2}{|c|}{$\begin{array}{c}\text { Total } \\
N=140\end{array}$} & \\
\hline & $\mathbf{N}$ & $\%$ & $\mathbf{N}$ & $\%$ & $\mathbf{N}$ & $\%$ & $\mathbf{N}$ & $\%$ & \\
\hline \multicolumn{10}{|l|}{ Gender } \\
\hline Male & 12 & $54.5 \%$ & 31 & $42.5 \%$ & 20 & $44.4 \%$ & 63 & $45.0 \%$ & 0.605 \\
\hline Female & 10 & $45.5 \%$ & 42 & $57.5 \%$ & 25 & $55.6 \%$ & 77 & $55.0 \%$ & \\
\hline Age, y (median, IQR) & 73 & $63-76$ & 66 & $60-74$ & 70 & $61-76$ & 70 & $60-76$ & \\
\hline \multicolumn{10}{|l|}{ Race } \\
\hline White & 22 & $100.0 \%$ & 68 & $93.2 \%$ & 42 & $93.3 \%$ & 132 & $94.3 \%$ & 0.613 \\
\hline Black & 0 & $0.0 \%$ & 0 & $0.0 \%$ & 0 & $0.0 \%$ & 0 & $0.0 \%$ & \\
\hline Asian & 0 & $0.0 \%$ & 1 & $1.4 \%$ & 1 & $2.2 \%$ & 2 & $1.4 \%$ & \\
\hline Hispanic & 0 & $0.0 \%$ & 4 & $5.5 \%$ & 1 & $2.2 \%$ & 5 & $3.6 \%$ & \\
\hline Other & 0 & $0.0 \%$ & 0 & $0.0 \%$ & 1 & $2.2 \%$ & 1 & $0.7 \%$ & \\
\hline CACI (median, IQR) & 4 & $3-5$ & 3 & $2-4$ & 3 & $3-4$ & 3 & $2-4$ & \\
\hline $\begin{array}{l}\text { BMI, } \mathrm{kg} / \mathrm{m}^{2} \text { (median, } \\
\text { IQR) }\end{array}$ & 24.4 & $23.5-27.9$ & 25.3 & $23.2-28.5$ & 26.5 & $22.1-30.1$ & 25.3 & $23.2-28.8$ & \\
\hline Smoking (Yes, ever) ${ }^{\mathrm{a}}$ & 20 & $90.9 \%$ & 45 & $61.6 \%$ & 10 & $22.2 \%$ & 75 & $53.6 \%$ & $<0.001$ \\
\hline Alcohol (Yes, ever) ${ }^{\mathrm{a}}$ & 16 & $72.7 \%$ & 23 & $31.5 \%$ & 12 & $26.7 \%$ & 51 & $36.4 \%$ & 0.001 \\
\hline $\begin{array}{l}\text { LOS, d (median, } \\
\text { IQR) }\end{array}$ & 7 & $6-9$ & 7 & $6-11$ & 7 & $6-9$ & 7 & $6-10$ & \\
\hline $\begin{array}{l}\text { Size, cm (median, } \\
\text { IQR) }\end{array}$ & 3.3 & $2.5-4.8$ & 3.4 & $2.5-4.3$ & 3.3 & $2.5-4.0$ & 3.3 & $2.5-4.3$ & \\
\hline \multicolumn{10}{|l|}{ Grade } \\
\hline Well differentiated & 1 & $4.5 \%$ & 2 & $2.7 \%$ & 1 & $2.2 \%$ & 4 & $2.9 \%$ & 0.388 \\
\hline $\begin{array}{l}\text { Moderately } \\
\text { differentiated }\end{array}$ & 10 & $45.5 \%$ & 50 & $68.5 \%$ & 25 & $55.6 \%$ & 85 & $60.7 \%$ & \\
\hline Poorly differentiated & 11 & $50.0 \%$ & 19 & $26.0 \%$ & 17 & $37.8 \%$ & 47 & $33.6 \%$ & \\
\hline Undifferentiated & 0 & $0.0 \%$ & 2 & $2.7 \%$ & 2 & $4.4 \%$ & 4 & $2.9 \%$ & \\
\hline Lymphnodes positive & 18 & $81.8 \%$ & 48 & $65.8 \%$ & 29 & $64.4 \%$ & 95 & $67.9 \%$ & 0.308 \\
\hline \multicolumn{10}{|l|}{ TNM Stage } \\
\hline IA & 0 & $0.0 \%$ & 4 & $5.5 \%$ & 0 & $0.0 \%$ & 4 & $2.9 \%$ & 0.216 \\
\hline IB & 1 & $4.5 \%$ & 9 & $12.3 \%$ & 4 & $8.9 \%$ & 14 & $10.0 \%$ & \\
\hline IIA & 3 & $13.6 \%$ & 10 & $13.7 \%$ & 12 & $26.7 \%$ & 25 & $17.9 \%$ & \\
\hline IIB & 18 & $81.8 \%$ & 50 & $68.5 \%$ & 29 & $64.4 \%$ & 97 & $69.3 \%$ & \\
\hline $\begin{array}{l}\text { Lymphovascular } \\
\text { invasion }^{\text {a }}\end{array}$ & 18 & $81.8 \%$ & 43 & $58.9 \%$ & 17 & $37.8 \%$ & 78 & $55.7 \%$ & 0.002 \\
\hline Perineural invasion & 20 & $90.9 \%$ & 62 & $84.9 \%$ & 43 & $95.6 \%$ & 125 & $89.3 \%$ & 0.187 \\
\hline \multicolumn{10}{|l|}{ Resection type } \\
\hline R0 & 15 & $68.2 \%$ & 50 & $68.5 \%$ & 24 & $53.3 \%$ & 89 & $63.6 \%$ & 0.223 \\
\hline R1 & 7 & $31.8 \%$ & 23 & $31.5 \%$ & 21 & $46.7 \%$ & 51 & $36.4 \%$ & \\
\hline
\end{tabular}

aStatistically significant differences between groups. CACI: age-adjusted Charlson Comorbidity Index; IQR: interquartile range. 
significant difference between the three FR $\alpha$ expression level groups in terms of gender, age, race, CACI, BMI, LOS, tumor size, grade, lymph node status, TNM stage, PNI or resection margin status of the PDAC patients.

\section{FR $\alpha$ expression intensity as a prognostic factor of overall survival}

Median overall survival (OS) and median followup for the complete cohort were 27.6 months (range 2.6138.8) and 20.4 months (range 2.6-138.8), respectively. Median OS of patients in the low, intermediate and high FR $\alpha$ expression intensity groups was 15.1 months (range 2.6-59.4), 24.0 months (range 2.9-138.8) and 36.3 months (range 3.4-133.2), respectively. One-, 3-, and 5-year OS rates were $56 \%, 21 \%, 13 \%$ for the low, $81 \%, 34 \%, 31 \%$ for the intermediate and $86 \%, 53 \%$, and $33 \%$ for the high FR $\alpha$ intensity groups, respectively (Table 2). In univariate analysis, high FR $\alpha$ intensity was associated with better OS $(p=0.006)$ (Figure 2). In multivariate analysis, FR $\alpha$ expression intensity $(\mathrm{HR}=0.61 ; \mathrm{p}=0.026)$ and $\mathrm{CACI}$ score $(H R=1.16 ; p=0.010)$ were shown to be independent predictors of OS for the entire cohort. Adjuvant chemoradiotherapy, chemotherapy alone, or radiotherapy alone were not associated with survival in either univariate or multivariate analyses.

\section{Expression of FR $\alpha$ on the surface of patient- derived PDAC cell lines and long-established PDAC cell lines}

To facilitate future in vitro-based studies in development of antibody or Chimeric Antigen Receptor (CAR) T-Cell based FR $\alpha$-targeted immunotherapies, we determined if $\mathrm{FR} \alpha$ is expressed on cell surface of PDAC cell lines. Seven human PDAC cell lines, AsPC-1, Capan-2, MIA PaCa-2, PANC-1 PDAC2, PDAC3, and PDAC5, were analyzed for cell surface expression of $\mathrm{FR} \alpha$ by flow cytometry analysis using APC- and PE-conjugated FR $\alpha$ specific antibodies, recognizing the same epitope. When the APC-conjugated antibody was used, FR $\alpha$ positive cells were present at a frequency of $6.3 \%, 1.0 \%, 2.4 \%$, $0.4 \%, 23.5 \%, 45.4 \%$, and $0.6 \%$, in AsPC-1, Capan-2, MIA PaCa-2, PANC-1 PDAC2, PDAC3, and PDAC5 cell lines, respectively. When the PE-conjugated antibody was employed, similar results were obtained for FR $\alpha$ positive cells on the above PDAC cell lines as 3.0\%, 1.3\%, 9.4\%, $0.2 \%, 24.1 \%, 33.8 \%$, and $1.0 \%$, respectively (Figure 3 ).
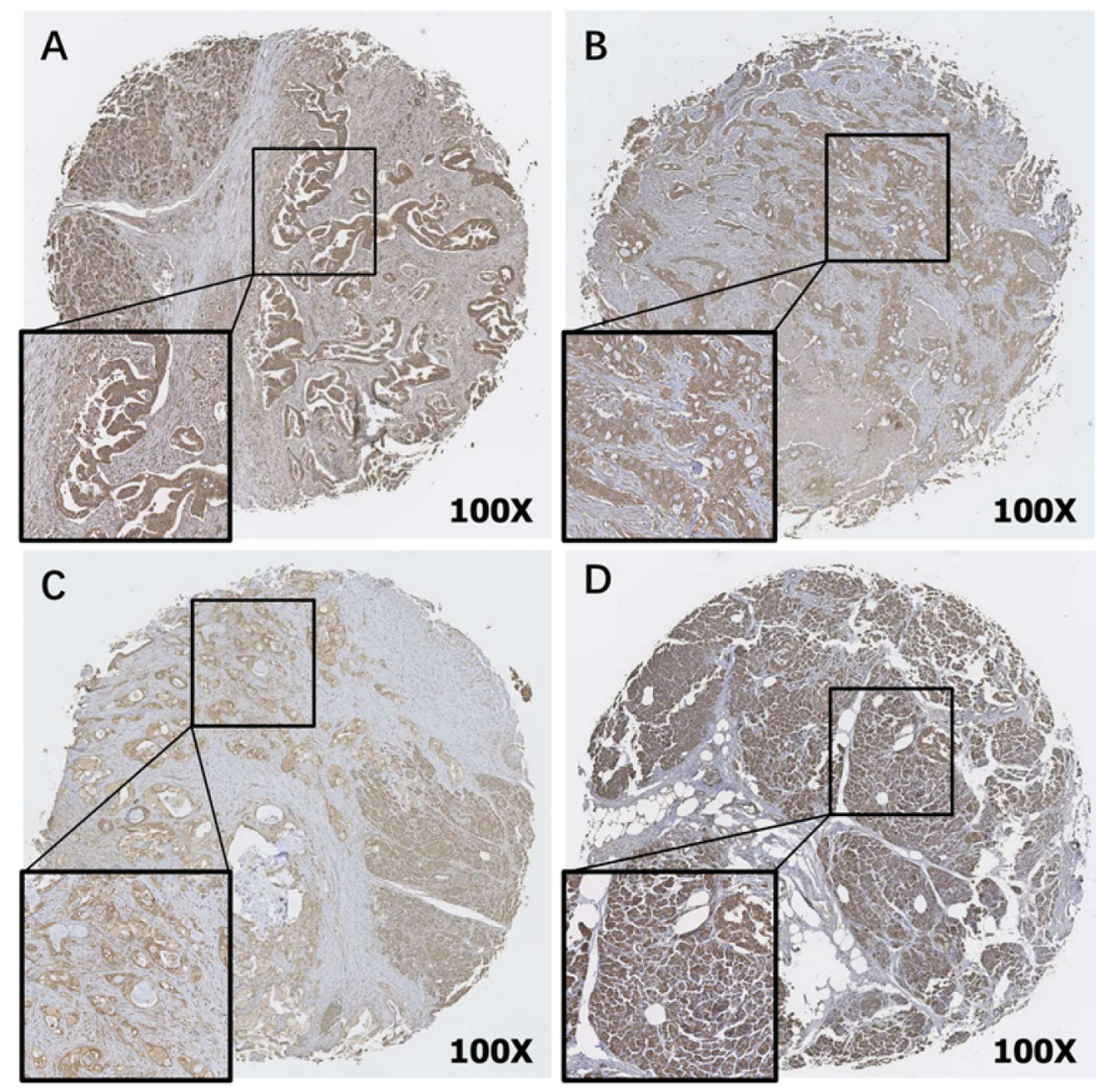

Figure 1: Immunohistochemical detection of Folate Receptor alpha (FR $\alpha)$ in TMAs of PDAC (A-C) and paraneoplasic normal pancreatic tissue (D) (original magnification 100X). Representative staining patterns of High (A), Intermediate (B) and Low (C) FR $\alpha$ expression intensity are shown. Paraneoplasic normal pancreatic tissue (D) was stained as a positive control.. 
Table 2: Distribution of FR $\alpha$ expression with the overall survival rate in PDAC

\begin{tabular}{lccccccc}
\hline FRa expression level & $\begin{array}{c}\text { Median survival } \\
\text { (months) }\end{array}$ & $\mathbf{9 5 \%}$ CIs & IQR & Range & $\begin{array}{c}\text { 1y OS } \\
(\%)\end{array}$ & $\begin{array}{c}\text { 3y OS } \\
(\%)\end{array}$ & $\begin{array}{c}\text { 5y OS } \\
(\%)\end{array}$ \\
\hline Low & 15.1 & $7.2-23.0$ & $7.1-31.1$ & $2.6-54.9$ & 56 & 21 & 13 \\
Intermediate & 24.0 & $17.5-30.6$ & $13.0-73.9$ & $2.9-138.8$ & 81 & 34 & 31 \\
High & 36.3 & $29.4-43.2$ & $24.6-\mathrm{n} / \mathrm{a}$ & $3.4-133.2$ & 86 & 53 & 33 \\
Total & 27.6 & $22.4-32.8$ & $12.2-73.9$ & $2.6-138.8$ & 79 & 38 & 28 \\
\hline
\end{tabular}

CI: confidence interval; IQR: interquartile range

\section{DISCUSSION}

In this study, which to our knowledge is the first of its kind to evaluate the prognostic value of FR $\alpha$ expression in PDAC, high FR $\alpha$ expression intensity in surgically removed PDAC specimens was found to be significantly associated with favorable prognosis. Previous reports have also shown correlations of FR $\alpha$ expression with prognosis in other malignancies. Interestingly, high FR $\alpha$ expression in lung adenocarcinoma was found to be associated with early stage disease and favorable prognosis [20, 27]; in contrast, high $\mathrm{FR} \alpha$ expression was shown to be associated with poor prognosis in breast cancer [28, 29] (but not relative to breast cancer brain metastases) [21], and with poor disease-free and overall survival, as well as chemoresistance in ovarian cancer [30-32]. In the present study, although we found that $\mathrm{FR} \alpha$ expression level was an independent predictor of survival, we did not

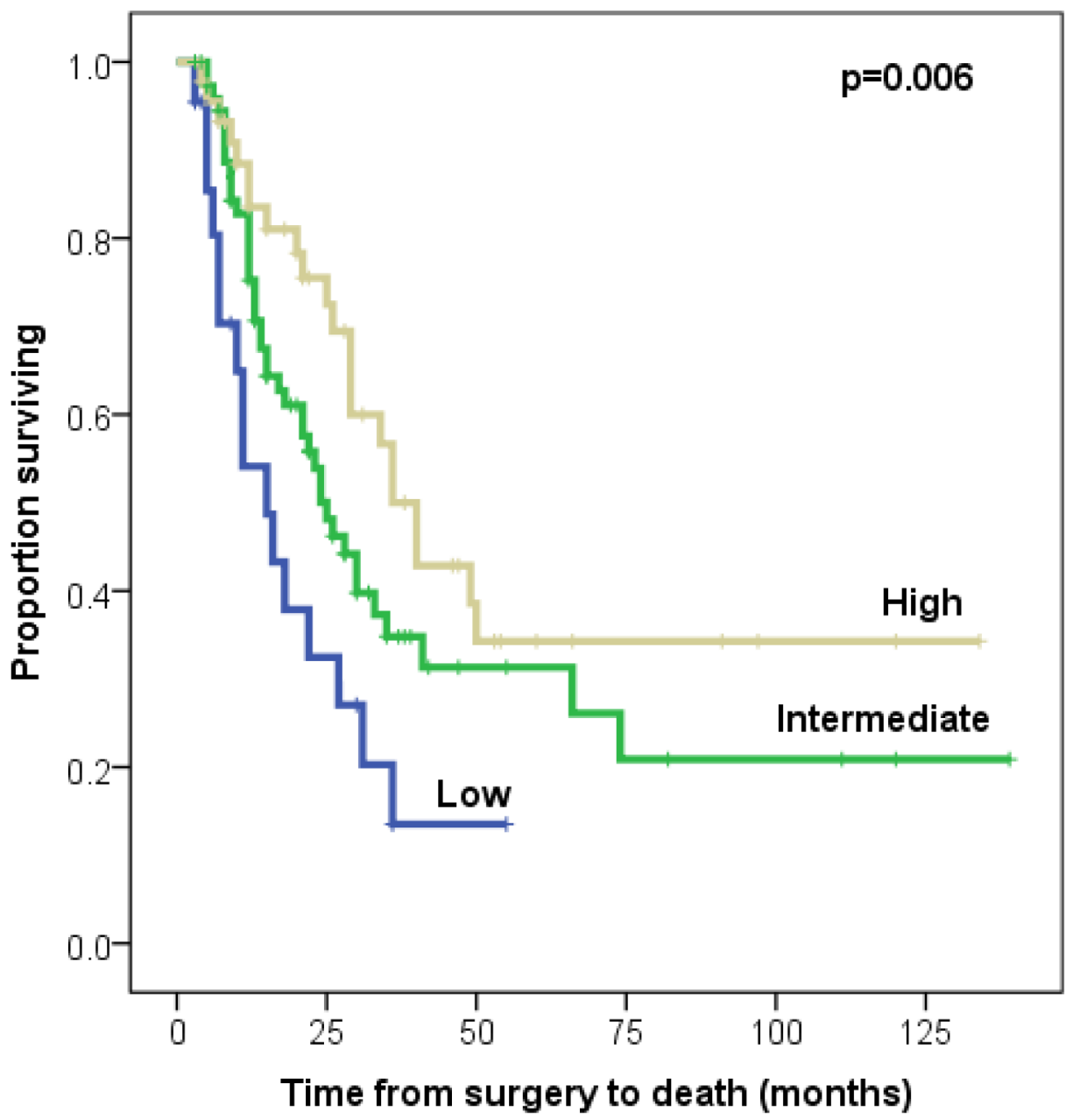

Figure 2: Kaplan-Meier survival curves of low vs. intermediate vs. high FRo expression intensity in 140 PDAC patients. 
find a correlation with tumor stage or grade. This result may reflect the small sample size of patients with stage 1a disease (only 4 cases), and with differentiated and undifferentiated tumors (4 cases each).

The reasons for the discrepancies between tumor types, as well as the mechanisms by which FR $\alpha$ is implicated in cancer progression remain largely unknown. It has been hypothesized that FR $\alpha$ plays a role in malignancies through both folate-related and unrelated mechanisms. While folate enters the cells in normal tissues mainly through the reduced folate receptor (RFC), in rapidly growing cells, such as malignant cells, the upregulation of $\mathrm{FR} \alpha$ accelerates folate uptake, thus facilitating growth [27]. Additionally, FR $\alpha$ can translocate to the nucleus and act as a transcription factor for developmental genes [33], or activate signaling pathways by inducing STAT3 activation $[34,35]$ and LYN tyrosine kinase phosphorylation $[24,36]$. However, FR $\alpha$ expression might simply be a "bystander" with no effect on cancer progression [15]. Indeed, in tumors in which
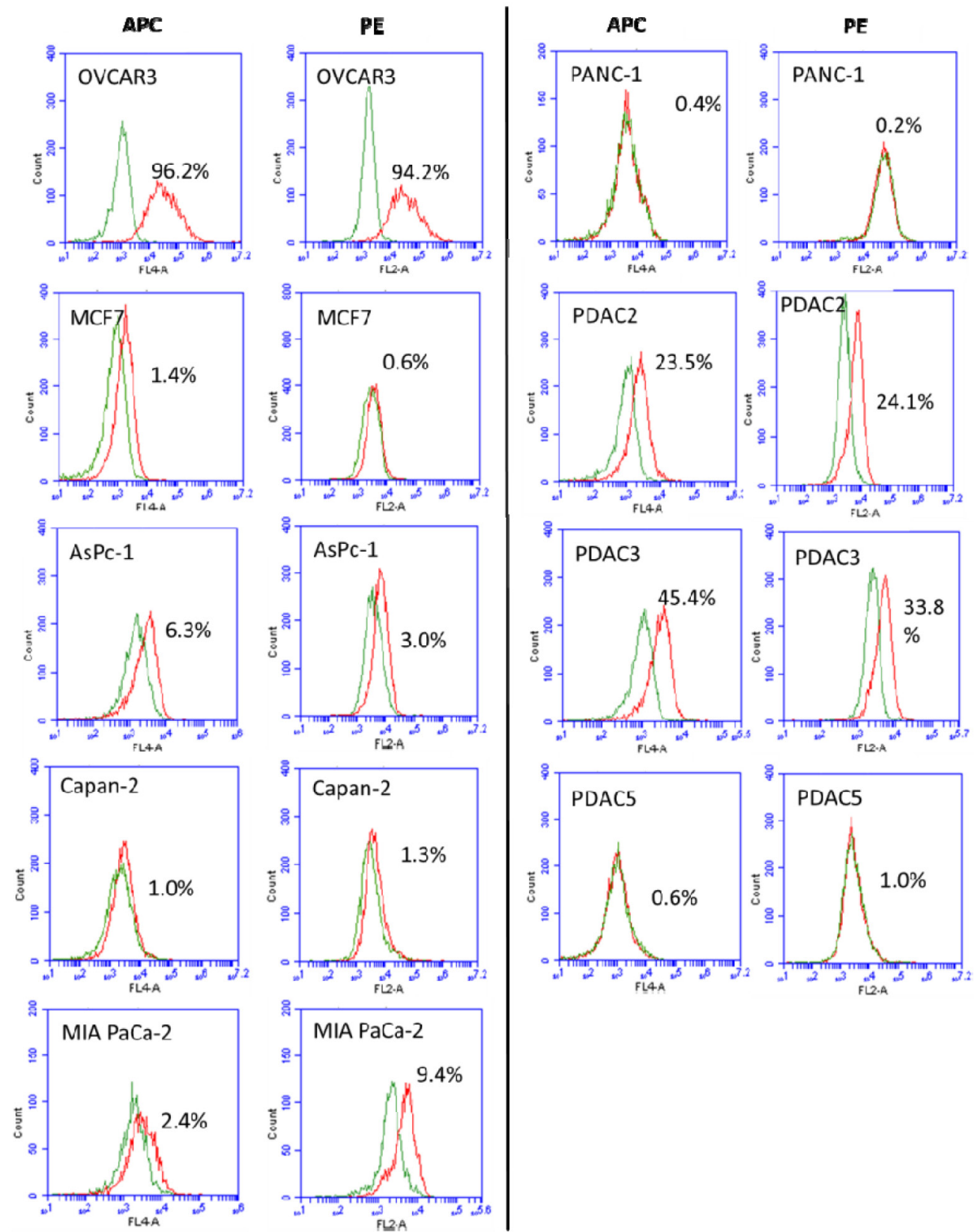

Figure 3: Analysis of FRa expression on human PDAC cell lines AsPC-1, Capan-2, MIA PaCa-2, PANC-1 PDAC2, PDAC3, and PDAC5. Cells were stained with either APC- or PE- conjugated FR $\alpha$-specific antibodies. Stained cells were subjected to flow cytometry analysis on a BD ACCURI C6 flow cytometer using BD CSampler software (Becton Dickinson and Company, San Jose, CA). OVCAR3 and MCF7 cells were used as positive and negative control, respectively. The percentage of cells stained with the FR $\alpha-$ specific antibodies is shown in each histogram (Green: conjugated negative antibody control; Red: conjugated FR $\alpha$-specific antibodies). 
high FR $\alpha$ expression confers better prognosis - lung adenocarcinoma and PDAC - FR $\alpha$ expression might just mirror the normal FR $\alpha$ expression of the non-cancerous cells of origin [27].

All the PDAC specimens analyzed in this study expressed FR $\alpha$, with more than $80 \%$ of cases presenting intermediate or high expression levels. As a result, FR $\alpha$ might be a promising target for novel therapeutic or diagnostic strategies. Several FR $\alpha$-based diagnostic and treatment modalities have been recently described in a variety of other malignancies and could potentially be applied in PDAC. FR $\alpha$-specific imaging probes, small molecules targeting $\mathrm{FR} \alpha$, drug conjugates [37], CAR $\mathrm{T}$ cells, vaccines, monoclonal antibodies and bispecific antibodies could all be potentially used for the improved diagnosis and treatment of PDAC [24]. Tempering these approaches, however, is the finding that normal and paraneoplastic pancreatic tissues were highly positive for FR $\alpha$ expression, in accordance with previous reports in which $40 \%-100 \%$ of normal pancreatic tissues were $\mathrm{FR} \alpha$ positive [27, 38]. Although this observation raises concerns about the specificity of FR $\alpha$-targeting regimens in PDAC, no pancreas-specific adverse effects have been reported in a number of clinical trials evaluating the safety and efficacy of such drugs [24].

The results of this study also established that low FR $\alpha$ expression in PDAC tissues correlated with smoking and alcohol consumption. Other studies have strongly suggested that smoking is an important factor which promotes pancreatic cancer. Together these findings suggest that FR $\alpha$ expression may be suppressed by smoking and alcohol. Determining the mechanisms underlying the effect of smoking compounds and/or alcohol on FR $\alpha$ expression may provide important insights into the pathogenesis and progression of pancreatic cancer. Of note, Iwakiri et al also demonstrated a downregulation of FR $\alpha$ in heavy smokers [20]. Given that diabetes and meat-rich diet have also been associated with poor prognosis in PDAC, future studies should attempt to elucidate the correlation between these factors and FR $\alpha$ expression levels.

In order to facilitate the conduction of experiments evaluating novel anti-cancer drugs for PDAC, we analyzed by flow cytometry the expression of $\mathrm{FR} \alpha$ on both long established (commercially available) and recently established patient-derived PDAC cell lines. Whereas, the long established cell lines AsPc-1, Capan-2 and PANC-1 were negative for FR $\alpha$ expression, the recently established cell lines PDAC2 and PDAC3 were positive. Of note, mRNA expression of the FOLR1 gene has also been found to be low for AsPc-1, MIA PaCa-2 and PANC-1 cell lines [39]. Our results provided fundamental information on FR $\alpha$ cell surface expression range at protein level on a panel of PDAC cell lines. This might serve well as a guide for the choice of PDAC cell lines to be used for mechanistic study of FR $\alpha$ expression in PDAC cells and FR $\alpha$ targeted approaches for PDAC.

Although the results of this study are limited due to the use of a polyclonal antibody for IHC, and from its single center design, they demonstrate that higher expression levels of FR $\alpha$ are predictive of a favorable prognosis in PDAC and FR $\alpha$ may represent a promising target for novel therapeutic strategies, including immunotherapy for PDAC.

\section{MATERIALS AND METHODS}

\section{Tissues and tissue microarrays (TMAs)}

The normal and tumor specimens from primary PDAC lesions were obtained from patients who underwent either pancreaticoduodenectomy or distal pancreatectomy at the Massachusetts General Hospital, between the years 1998 to 2012. Clinicopathologic information available included patient age, gender, race, age-adjusted Charlson Comorbidity Index (CACI) [40], Body Mass Index (BMI), smoking, alcohol consumption, length of hospital stay (LOS), tumor size, tumor grade, tumor stage, lymphovascular invasion, perineural invasion, resection margin status (R0 or R1, defined as margins $>1 \mathrm{~mm}$ or $</=1 \mathrm{~mm}$, respectively) [41] and survival data. Surgical specimens were processed within 25 minutes after surgical excision. Tissue samples were fixed in $20 \%$ buffered formalin and embedded in paraffin following conventional procedures. PDAC tumors were confirmed histopathologically by a gastrointestinal pathologist (V. Deshpande) according to the AJCC (7th Edition) and the WHO classification systems. A TMA was constructed with three to five 3-mm cores per patient before the procedure of immunohistochemistry. This study was approved by the Institutional Review Board (protocol number: 2002P000154).

\section{Cell lines}

The PDAC cell lines AsPC-1, Capan-2, MIA PaCa2 and PANC-1 were purchased from ATCC; PDAC2, PDAC3 and PDAC5 were generated from metastatic ascites fluid from patients receiving treatment at the Department of Surgery, Massachusetts General Hospital [42]. The cell lines OVCAR3 and MCF7 were purchased from ATCC and used as a positive [43] and negative [44] control for FR $\alpha$ expression, respectively.

\section{Immunohistochemical (IHC) staining}

TMA blocks of tumor specimens were cut into $5-\mu \mathrm{m}$ sections and were used as substrates in IHC reactions (Normal pancreas tissue and stroma were used as the positive and negative control, respectively). IHC staining was performed with Rabbit Polyclonal (IgG) to 
Human FOLR1/Folate Receptor Alpha Antibody (LSB5727, LSBio) using the EnVision+ system (Dako) Kit. Briefly, TMA specimens were sectioned at $5 \mu \mathrm{m}$ onto positively-charged glass slides and heated for 12 hours at $65^{\circ} \mathrm{C}$. Slides were deparaffinized in 3 sequential baths of xylene for $5 \mathrm{~min}$ each, transferred to 2 sequential baths of $100 \%$ alcohol for $30 \mathrm{sec}$ each, followed by one bath of $95 \%$ alcohol for $30 \mathrm{sec}$, followed by 2 sequential baths of $75 \%$ alcohol for $30 \mathrm{sec}$ each and then rinsed for $5 \mathrm{~min}$ in deionized (DI) water. For antigen retrieval, slides were incubated for $20 \mathrm{~min}$ in the diluted Target Retrieval Solution 10X Concentrate (DAKO, S1699) in which the container incubation reaches a maximum of $100^{\circ} \mathrm{C}$ and then cooled for 1 hour and $30 \mathrm{~min}$ down to room temperature (RT). After cooling to RT, slides were placed into 3\% Hydrogen Peroxide Solution (Sigma) for 20min at RT and subsequently washed in 3 sequential baths of Tris Buffered Saline/0.1\% Tween-20 wash buffer (TBST) for 5 min each. After washing in TBST, slides were incubated with $1 \% \mathrm{BSA} / 5 \%$ NHS in TBST (Blocking Reagent) for 1 hour at RT. Subsequently, slides were incubated overnight at $4{ }^{\circ} \mathrm{C}$ with Rabbit Polyclonal (IgG) to Human FOLR1 antibody (LS-B5727, LSBio) at a concentration of $5 \mu \mathrm{g} /$ $\mathrm{mL}$ diluted in blocking reagent. After washing in TBST for 5 sequential baths, slides were incubated with DAKO envision + system -HRP labeled polymer anti-rabbit at RT for 45 min. Following 3 sequential baths, slides were incubated with Dako Liquid DAB + Substrate Chromogen System for $10 \mathrm{sec}$ and counterstained with hematoxylin (Dako) for 30sec, all incubations being performed at RT. After dehydration, slides were covered with cover glasses.

\section{IHC scoring method}

Staining intensity of stained tumor cells in each lesion was reviewed independently by two investigators (LC and TM) and was confirmed by a gastrointestinal pathologist (Qi Shen) using a Nikon Eclipse 80i microscope (Nikon, Japan). Investigators were blinded to the patients' characteristics and clinical outcomes. The locations of FR $\alpha$ staining were marked as: cytoplasm, membrane, cytoplasm and membrane, using 10x, 20x and 40x objectives. The staining was scored based on the intensity as 1-Low (negative or weak staining); 2-Intermediate (moderate staining); and 3-High (strong staining). Normal pancreatic cells, which were stained with high intensity in all specimens, were used as a control of high intensity. Tumor stroma, where staining was absent in all specimens, was used as a negative control. Staining intensity in-between that of normal pancreatic cells and stroma was considered "intermediate". Since all tumor cells in the same lesion had the same staining intensity, the percentage of stained cells for each intensity category was not taken into account. The mean intensity was calculated as (sum of intensity scores / numbers of cores analyzed) for each patient. Thereafter, the mean was rounded to the closest integer and the respective score was given (1- low, 2-intermediate, 3-high). Patients for whom less than three cores were available after the staining process were excluded from further analysis.

\section{Flow cytometry analysis}

Cells were stained with antibodies specific to FR $\alpha$ by flow cytometry as previously described [45]. Two mouse IgG monoclonal anti-FR $\alpha$ antibodies recognizing FR $\alpha$ Arg25-Met233 were independently used. One was conjugated with PE (FAB5646P, R\&D Systems) and the other with APC (LS-C129132, LSBio). We used both antibodies to test our flow cytometry assay reproducibility. Briefly, cells $\left(1 \times 10^{5}\right)$ were resuspended in phosphatebuffered saline (PBS; pH 7.4) (Gibco) containing 2\% BSA in $5 \mathrm{ml}$ Polystyrene Round-Bottom tubes (BD Falcon, BD-352001) and incubated with the anti- FR $\alpha$ antibodies. After washing twice with PBS, cells were resuspended in PBS containing 2\% PFA for flow cytometry analysis. Five thousand gated events were analyzed by flow cytometry on a BD ACCURI C6 using BD CSampler software (Becton Dickinson and Company, San Jose, CA). The ovarian cancer cell line OVCAR3 and the breast cancer cell line MCF7 were used as the positive and negative control, respectively, for FR $\alpha$ expression.

\section{Statistical analysis}

The chi-square test was used to compare categorical variables between groups, while one-way ANOVA was used for continuous variables. The inter-rater reliability was assessed using Cohen's $\kappa$. Overall survival (OS) was calculated as time between the date of operation and the date of death (event) or last follow up (censored). Survival curves were plotted with the Kaplan-Meier method and differences in survival between groups was analyzed utilizing the log-rank test. Multivariate survival analyses were conducted using a stepwise backward Cox proportional hazards survival model. A p-value less than 0.05 was considered to be statistically significant and all tests used were 2-tailed. All statistical analyses were performed with IBM SPSS Statistics for Windows, Version 21.0 (IBM Corp., Armonk, NY).

\section{Abbreviations}

AJCC: American Joint Committee on Cancer; ATCC: American Type Culture Collection; BMI: Body mass index; BSA: Bovine serum albumin; CACI: age-adjusted Charlson Comorbidity Index; CAR T-Cells: Chimeric Antigen Receptor T-Cells; CI: confidence interval; DNA: Deoxyribonucleic acid; FBP: Folate binding protein; FR $\alpha$ : Folate receptor alpha; FR $\beta$ : Folate receptor beta; FR $\gamma$ : Folate receptor gamma; IHC: Immunohistochemistry; IQR: interquartile range; LOS: Length of hospital stay; PBS: Phosphate buffered saline; PDAC: Pancreatic ductal adenocarcinoma; PNI: Perineural invasion; RFC: Reduced 
folate receptor; RNA: Ribonucleic acid; RT: Room temperature; OS: Overall survival; TBS: Tris-buffered saline; TMA: Tissue microarray

\section{Author contributions}

Conception and design: Lei Cai, Theodoros Michelakos, Xinhui Wang

Development of methodology: Lei Cai, Theodoros Michelakos, Cristina R. Ferrone, Qi Shen, Vikram Deshpande, Teppei Yamada

Analysis and interpretation of data: Lei Cai, Theodoros Michelakos, Liyuan Zhang, Qi Shen, Gong Zhang

Writing, review, and/or revision of the manuscript: Lei Cai, Theodoros Michelakos, Albert DeLeo, Xinhui Wang

Study supervision: Xinhui Wang, Cristina R. Ferrone, Soldano Ferrone.

\section{CONFLICTS OF INTEREST}

The authors declare no conflicts of interest.

\section{FUNDING}

This work was supported by NCI R21 CA181851(X.W.), Massachusetts General Hospital ECOR Deliberative Interim Support Funding (X.W.), Massachusetts General Hospital ECOR Formulaic Bridge Funding (X.W.), NCI R21 CA164756 (S.F. and C.R.F.), National Natural Science Foundation of China 81201948 (L.C.), China Scholarship Council Foundation 201203170045 (L.C.) and Natural Science Foundation of Chongqing cstc2012jjA0337 (L.C.).

\section{REFERENCES}

1. Siegel RL, Miller KD, Jemal A. Cancer statistics, 2016. CA Cancer J Clin. 2016; 66:7-30.

2. Seufferlein T, Bachet JB, Van Cutsem E, Rougier P, Group EGW. Pancreatic adenocarcinoma: ESMO-ESDO Clinical Practice Guidelines for diagnosis, treatment and follow-up. Ann Oncol. 2012; 23:vii33-40.

3. Hidalgo M. Pancreatic cancer. N Engl J Med. 2010; 362:1605-1617.

4. Edderkaoui M, Xu S, Chheda C, Morvaridi S, Hu RW, Grippo PJ, Mascarinas E, Principe DR, Knudsen B, Xue J, Habtezion A, Uyeminami D, Pinkerton KE, Pandol SJ. HDAC3 mediates smoking-induced pancreatic cancer. Oncotarget. 2016; 7:7747-7760. doi: 10.18632/oncotarget.6820.

5. Pandol SJ, Apte MV, Wilson JS, Gukovskaya AS, Edderkaoui M. The burning question: why is smoking a risk factor for pancreatic cancer? Pancreatology. 2012; $12: 344-349$
6. Welsch T, Kleeff J, Seitz HK, Buchler P, Friess H, Buchler MW. Update on pancreatic cancer and alcohol-associated risk. J Gastroenterol Hepatol. 2006; 21:S69-75.

7. Becker AE, Hernandez YG, Frucht H, Lucas AL. Pancreatic ductal adenocarcinoma: risk factors, screening, and early detection. World J Gastroenterol. 2014; 20:11182-11198.

8. Nipp RD, Zanconato A, Zheng H, Ferrone CR, Lillemoe KD, Wo JY, Hong TS, Clark JW, Ryan DP, Fernandez-Del Castillo C. Predictors of Early Mortality After Surgical Resection of Pancreatic Adenocarcinoma in the Era of Neoadjuvant Treatment. Pancreas. 2017; 46:183-189.

9. Hessmann E, Johnsen SA, Siveke JT, Ellenrieder V. Epigenetic treatment of pancreatic cancer: is there a therapeutic perspective on the horizon? Gut. 2017; 66:168-179.

10. Rijnboutt S, Jansen G, Posthuma G, Hynes JB, Schornagel JH, Strous GJ. Endocytosis of GPI-linked membrane folate receptor-alpha. J Cell Biol. 1996; 132:35-47.

11. Shen F, Ross JF, Wang X, Ratnam M. Identification of a novel folate receptor, a truncated receptor, and receptor type beta in hematopoietic cells: cDNA cloning, expression, immunoreactivity, and tissue specificity. Biochemistry. 1994; 33:1209-1215.

12. Elnakat H, Ratnam M. Distribution, functionality and gene regulation of folate receptor isoforms: implications in targeted therapy. Adv Drug Deliv Rev. 2004; 56:1067-1084.

13. O'Shannessy DJ, Jackson SM, Twine NC, Hoffman BE, Dezso Z, Agoulnik SI, Somers EB. Gene expression analyses support fallopian tube epithelium as the cell of origin of epithelial ovarian cancer. Int J Mol Sci. 2013; 14:13687-13703.

14. Necela BM, Crozier JA, Andorfer CA, Lewis-Tuffin L, Kachergus JM, Geiger XJ, Kalari KR, Serie DJ, Sun Z, Moreno-Aspitia A, O'Shannessy DJ, Maltzman JD, McCullough AE, et al. Folate receptor- $\alpha$ (FOLR1) expression and function in triple negative tumors. PLoS One. 2015; 10:e122209.

15. Kelemen LE. The role of folate receptor alpha in cancer development, progression and treatment: cause, consequence or innocent bystander? Int J Cancer. 2006; 119:243-250.

16. Ding Z, Li B, Wang Q, Miao Y, Lu X. Increase in folate receptor alpha expression in nonfunctional pituitary adenomas. Turk Neurosurg. 2015; 25:298-304.

17. Driver BR, Barrios R, Ge Y, Haque A, Tacha D, Cagle PT. Folate Receptor alpha Expression Level Correlates With Histologic Grade in Lung Adenocarcinoma. Arch Pathol Lab Med. 2016; 140:682-685.

18. Shi H, Guo J, Li C, Wang Z. A current review of folate receptor alpha as a potential tumor target in non-small-cell lung cancer. Drug Des Devel Ther. 2015; 9:4989-4996.

19. Nunez MI, Behrens C, Woods DM, Lin H, Suraokar M, Kadara H, Hofstetter W, Kalhor N, Lee JJ, Franklin W, 
Stewart DJ, Wistuba, II. High expression of folate receptor alpha in lung cancer correlates with adenocarcinoma histology and EGFR [corrected] mutation. J Thorac Oncol. 2012; 7:833-840.

20. Iwakiri S, Sonobe M, Nagai S, Hirata T, Wada H, Miyahara R. Expression status of folate receptor alpha is significantly correlated with prognosis in non-small-cell lung cancers. Ann Surg Oncol. 2008; 15:889-899.

21. Leone JP, Bhargava R, Theisen BK, Hamilton RL, Lee AV, Brufsky AM. Expression of high affinity folate receptor in breast cancer brain metastasis. Oncotarget. 2015; 6:3032730333. doi: 10.18632/oncotarget.4639.

22. Figueiredo JC, Levine AJ, Lee WH, Conti DV, Poynter JN, Campbell PT, Duggan D, Lewinger JP, Martinez ME, Ulrich CM, Newcomb P, Potter J, Limburg PJ, et al. Genes involved with folate uptake and distribution and their association with colorectal cancer risk. Cancer Causes Control. 2010; 21:597-608.

23. Farkas SA, Befekadu R, Hahn-Stromberg V, Nilsson TK. DNA methylation and expression of the folate transporter genes in colorectal cancer. Tumour Biol. 2015; 36:5581-5590.

24. Cheung A, Bax HJ, Josephs DH, Ilieva KM, Pellizzari G, Opzoomer J, Bloomfield J, Fittall M, Grigoriadis A, Figini M, Canevari S, Spicer JF, Tutt AN, Karagiannis SN. Targeting folate receptor alpha for cancer treatment. Oncotarget. 2016; 7:52553-52574. doi: 10.18632/oncotarget.9651.

25. Leung F, Dimitromanolakis A, Kobayashi H, Diamandis EP, Kulasingam V. Folate-receptor 1 (FOLR1) protein is elevated in the serum of ovarian cancer patients. Clin Biochem. 2013; 46:1462-1468.

26. Wen Y, Graybill WS, Previs RA, Hu W, Ivan C, Mangala LS, Zand B, Nick AM, Jennings NB, Dalton HJ, Sehgal $\mathrm{V}$, Ram P, Lee JS, et al. Immunotherapy targeting folate receptor induces cell death associated with autophagy in ovarian cancer. Clin Cancer Res. 2015; 21:448-459.

27. O'Shannessy DJ, Yu G, Smale R, Fu YS, Singhal S, Thiel RP, Somers EB, Vachani A. Folate receptor alpha expression in lung cancer: diagnostic and prognostic significance. Oncotarget. 2012; 3:414-425. doi: 10.18632/oncotarget.489.

28. Hartmann LC, Keeney GL, Lingle WL, Christianson TJ, Varghese B, Hillman D, Oberg AL, Low PS. Folate receptor overexpression is associated with poor outcome in breast cancer. Int J Cancer. 2007; 121:938-942.

29. Zhang Z, Wang J, Tacha DE, Li P, Bremer RE, Chen H, Wei B, Xiao X, Da J, Skinner K, Hicks DG, Bu H, Tang P. Folate receptor alpha associated with triple-negative breast cancer and poor prognosis. Arch Pathol Lab Med. 2014; 138:890-895.

30. Toffoli G, Cernigoi C, Russo A, Gallo A, Bagnoli M, Boiocchi M. Overexpression of folate binding protein in ovarian cancers. Int J Cancer. 1997; 74:193-198.
31. Toffoli G, Russo A, Gallo A, Cernigoi C, Miotti S, Sorio R, Tumolo S, Boiocchi M. Expression of folate binding protein as a prognostic factor for response to platinum-containing chemotherapy and survival in human ovarian cancer. Int $\mathbf{J}$ Cancer. 1998; 79:121-126.

32. Vergote IB, Marth C, Coleman RL. Role of the folate receptor in ovarian cancer treatment: evidence, mechanism, and clinical implications. Cancer Metastasis Rev. 2015; 34:41-52.

33. Boshnjaku V, Shim KW, Tsurubuchi T, Ichi S, Szany EV, Xi G, Mania-Farnell B, McLone DG, Tomita T, Mayanil CS. Nuclear localization of folate receptor alpha: a new role as a transcription factor. Sci Rep. 2012; 2:980.

34. Yang Y, Li X, Sun Q, He B, Jia Y, Cai D, Zhao R. Folate deprivation induces cell cycle arrest at G0/G1 phase and apoptosis in hippocampal neuron cells through downregulation of IGF-1 signaling pathway. Int J Biochem Cell Biol. 2016; 79:222-230.

35. Hansen MF, Greibe E, Skovbjerg S, Rohde S, Kristensen AC, Jensen TR, Stentoft C, Kjaer KH, Kronborg CS, Martensen PM. Folic acid mediates activation of the prooncogene STAT3 via the Folate Receptor alpha. Cell Signal. 2015; 27:1356-1368.

36. Miotti S, Bagnoli M, Tomassetti A, Colnaghi MI, Canevari $\mathrm{S}$. Interaction of folate receptor with signaling molecules lyn and G(alpha)(i-3) in detergent-resistant complexes from the ovary carcinoma cell line IGROV1. J Cell Sci. 2000; 113:349-357.

37. Ab O, Whiteman KR, Bartle LM, Sun X, Singh R, Tavares D, LaBelle A, Payne G, Lutz RJ, Pinkas J, Goldmacher VS, Chittenden T, Lambert JM. IMGN853, a Folate Receptoralpha (FRalpha)-Targeting Antibody-Drug Conjugate, Exhibits Potent Targeted Antitumor Activity against FRalpha-Expressing Tumors. Mol Cancer Ther. 2015; 14:1605-1613.

38. Parker N, Turk MJ, Westrick E, Lewis JD, Low PS, Leamon CP. Folate receptor expression in carcinomas and normal tissues determined by a quantitative radioligand binding assay. Anal Biochem. 2005; 338:284-293.

39. Barretina J, Caponigro G, Stransky N, Venkatesan K, Margolin AA, Kim S, Wilson CJ, Lehar J, Kryukov GV, Sonkin D, Reddy A, Liu M, Murray L, et al. The Cancer Cell Line Encyclopedia enables predictive modelling of anticancer drug sensitivity. Nature. 2012; 483:603-607.

40. Dias-Santos D, Ferrone CR, Zheng H, Lillemoe KD, Fernandez-Del Castillo C. The Charlson age comorbidity index predicts early mortality after surgery for pancreatic cancer. Surgery. 2015; 157:881-887.

41. Konstantinidis IT, Warshaw AL, Allen JN, Blaszkowsky LS, Castillo CF, Deshpande V, Hong TS, Kwak EL, Lauwers GY, Ryan DP, Wargo JA, Lillemoe KD, Ferrone CR. Pancreatic ductal adenocarcinoma: is there a survival difference for R1 resections versus locally advanced 
unresectable tumors? What is a "true" R0 resection? Ann Surg. 2013; 257:731-736.

42. Ting DT, Wittner BS, Ligorio M, Vincent Jordan N, Shah AM, Miyamoto DT, Aceto N, Bersani F, Brannigan BW, Xega K, Ciciliano JC, Zhu H, MacKenzie OC, et al. Singlecell RNA sequencing identifies extracellular matrix gene expression by pancreatic circulating tumor cells. Cell Rep. 2014; 8:1905-1918.

43. Miotti S, Bagnoli M, Ottone F, Tomassetti A, Colnaghi MI, Canevari S. Simultaneous activity of two different mechanisms of folate transport in ovarian carcinoma cell lines. J Cell Biochem. 1997; 65:479-491.
44. Yin JJ, Sharma S, Shumyak SP, Wang ZX, Zhou ZW, Zhang Y, Guo P, Li CZ, Kanwar JR, Yang T, Mohapatra SS, Liu W, Duan W, et al. Synthesis and biological evaluation of novel folic acid receptor-targeted, beta-cyclodextrin-based drug complexes for cancer treatment. PLoS One. 2013; 8:e62289.

45. Wang X, Osada T, Wang Y, Yu L, Sakakura K, Katayama A, McCarthy JB, Brufsky A, Chivukula M, Khoury T, Hsu DS, Barry WT, Lyerly HK, et al. CSPG4 protein as a new target for the antibody-based immunotherapy of triple-negative breast cancer. J Natl Cancer Inst. 2010; 102:1496-1512. 